\title{
Differences in skin characteristics in European (Large White) and Caribbean (Creole) growing pigs with reference to thermoregulation*
}

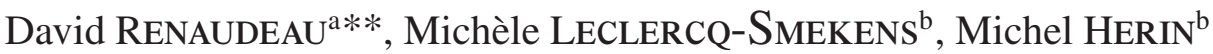

\author{
${ }^{\text {a }}$ Institut National de la Recherche Agronomique (INRA), Station de Recherches Zootechniques, \\ 97170 Petit Bourg, Guadeloupe, F.W.I., France \\ ${ }^{\mathrm{b}}$ Laboratoire Cellules et Tissus, Faculté de médecine, Facultés Universitaires Notre Dame de la Paix, \\ 51 rue de Bruxelles, 5000 Namur, Belgium
}

(Received 19 July 2005 - Accepted 2 February 2006)

\begin{abstract}
The effects of breed and season on histological skin characteristics were studied at the experimental facilities of INRA in Guadeloupe ( $16^{\circ}$ Lat. N., $61^{\circ}$ Long. W. $)$ in two replicates using a total of 20 Creole (CR) and 20 Large White (LW) pigs. The first replicate was carried out during the warm season (i.e., between February and April) and the second during the hot season (i.e., between August and October). In the warm season, ambient temperature and relative humidity averaged $25.3{ }^{\circ} \mathrm{C}$ and $86.0 \%$, respectively. The corresponding values for the hot season were $27.9^{\circ} \mathrm{C}$ and $83.6 \%$. At $90 \mathrm{~kg} \mathrm{BW}$, all pigs were slaughtered and a 2 to $4 \mathrm{~cm}^{2}$ sample of cutaneous tissue from the back region (i.e., at the last dorsal rib level) was taken from each animal before scalding and dehairing. Slices were stained with trichrome blue staining and the thickness of the epidermis and dermis were determined. The density and surface of the sweat glands (SG) were also determined. The mast cell density was measured using slices stained with Giemsa. Epidermis thickness was not affected by breed or season and averaged $55 \mu \mathrm{m}$. However, dermis thickness was significantly higher in CR than in LW pigs ( 3.60 vs. $3.13 \mathrm{~mm} ; P<0.01)$ but it was not influenced by season (3.36 $\mathrm{mm}$ on average; $P=0.17$ ). The density of $\mathrm{SG}$ was significantly higher in $\mathrm{CR}$ than in LW pigs (32.0 vs. $25.4 \mathrm{SG}$ per $\left.\mathrm{mm}^{2} ; P<0.01\right)$ but their surface area was lower in CR than in LW pigs $(106$ vs. $263 \times 10^{-3} \mu \mathrm{m}^{2}$ per $\left.\mathrm{mm}^{2} ; P<0.01\right)$. The SG density tended to be higher in the hot than in the warm season (30.4 vs. $26.9 \mathrm{SG}$ per $\mathrm{mm}^{2} ; P=0.0971$ ). Mast cell density in the dermis was found to be higher in CR than in LW pigs $\left(2.52\right.$ vs. 1.38 mast cells per $\left.\mathrm{mm}^{2} ; P<0.01\right)$. Irrespective of the breed, mast cell density was higher during the hot than the warm season $(2.22 \mathrm{vs}$. 1.68 mast cells per $\left.\mathrm{mm}^{2} ; P<0.01\right)$. In conclusion, our study suggests that the differences in skin histology and/or sweat gland histometry could partly explain the better heat tolerance in CR pigs.
\end{abstract}

pigs / heat tolerance / breed / skin / histology

\footnotetext{
* This work was supported by the Guadeloupe region and the European Union (FEOGA-FEDER).

** Corresponding author: David.Renaudeau@antilles.inra.fr
} 
Résumé - Les effets du type génétique et de la saison sur les caractéristiques histologiques de la peau ont été étudiés l'INRA de Guadeloupe ( $16^{\circ}$ Lat. N., $61^{\circ}$ Long. W. $)$ sur un total de 20 porcs Créole $(\mathrm{CR})$ et 20 porcs Large White $(\mathrm{LW})$ répartis en deux répétitions. La première répétition s'est déroulée au cours de la saison fraîche (entre février et avril) et la seconde au cours de la saison chaude (entre août et octobre). En saison fraîche, la température et l'humidité relative moyenne étaient respectivement de $25,3{ }^{\circ} \mathrm{C}$ et $86,0 \%$. Les valeurs correspondantes pour la saison chaude étaient de $27,9^{\circ} \mathrm{C}$ et $83,6 \%$. Au poids vif de $90 \mathrm{~kg}$, tous les porcs ont été abattus et un échantillon de peau de 2 à $4 \mathrm{~cm}^{2}$ a été prélevé au niveau du dos (i.e., au niveau de la dernière côte dorsale) avant l'échaudage et l'épilation. Les épaisseurs de l'épiderme et du derme ont été déterminées sur des coupes de peau colorées au trichrome bleu. La densité et la surface des glandes sudoripares (SG) ont également été mesurées. La densité des mastocytes a été déterminée sur des coupes colorées au Giemsa. L'épaisseur de l'épiderme n'est pas affectée par le type génétique ou par la saison (55 $\mu \mathrm{m}$ en moyenne). En revanche, l'épaisseur du derme est significativement plus importante chez le CR comparativement au LW (3,60 vs. $3,13 \mathrm{~mm} ; P<0,01)$ mais n'est pas influencée par la saison (3,36 mm en moyenne; $P=0,17)$. La densité des glandes sudoripares est significativement plus importante chez le porc CR par rapport au LW (32,0 vs. 25,4 SG par $\left.\mathrm{mm}^{2} ; P<0,01\right)$ mais leur surface est plus faible chez le porc CR par rapport au LW (106 vs. $263 \times 10^{-3} \mu \mathrm{m}^{2}$ par $\mathrm{mm}^{2}$; $P<0,01)$. La densité des $\mathrm{SG}$ tend à être plus élevée en saison chaude comparativement à la saison fraîche $\left(30,4\right.$ vs. $26,9 \mathrm{SG}$ par $\left.\mathrm{mm}^{2} ; P=0,097\right)$. Dans le derme, la densité des mastocytes est significativement plus élevée chez le porc CR par rapport au LW (2,52 vs. 1,38 mastocytes par $\left.\mathrm{mm}^{2} ; P<0,01\right)$. Quelque soit la race, la densité des mastocytes est plus importante au cours de la saison chaude comparativement à la saison fraîche $\left(2,22\right.$ vs. 1,68 mastocytes par $\left.\mathrm{mm}^{2} ; P<0,01\right)$. En conclusion, notre étude montre que les différences d'histologie de la peau ou des caractéristiques des glandes sudoripares entre les deux types génétiques pourraient en partie expliquer la meilleure adaptation du porc CR.

porcs / tolérance à la chaleur / race / peau / histologie

\section{INTRODUCTION}

Like other homeothermic animals, the pig maintains a constant body temperature under varying environmental conditions by regulating heat loss and heat production. This ability to regulate body temperature under heat stress is affected by environmental factors (feeding level, space allocation, floor type, relative humidity) and animal related factors (physiological and immune status, body weight, age, genotype) [13]. Breed differences with regard to heat tolerance are reported to exist in halothane positive and negative boars [10] and in high and low producing lines [22]. Recently, the effects of short term and long term exposure to high ambient temperature were found to be attenuated in a local Caribbean (Creole) breed in comparison with a European genotype (Large White) [23]. In these latter studies, mechanisms implicated in better tolerance to heat stress are unknown but can be attributed to a re- duction in total heat production due to their lower performance and/or increase of heat dissipation capacity (evaporative and sensible heat loss). Because pigs have few sweat glands, a large part of water is lost by evaporation in the respiratory tract [16]. Moreover, the skin plays a key role in thermoregulation in pigs since it controls the rate of sensible heat transfer from the body core to the surface. Within the thermoneutral range of ambient temperature the loss of sensible heat from the body is mainly controlled by adjustment of tissue insulation in particular by change in peripheral blood flow [15]. In accordance with the results obtained in cattle [8], histological changes in the skin structure (number of epithelial strata, dermis thickness...) can also be implicated in body heat transfer.

The objective of this study was to compare skin histology of a Caribbean breed (i.e., Creole) with that of an imported European breed (i.e., Large White) based on 
the hypothesis that breed explains differences in heat tolerance level and heat loss capacity at the cutaneous level. The results on the effect of breed and season on growth performance and feeding behaviour have been previously published [24].

\section{MATERIALS AND METHODS}

A total of 40 castrated pigs (20 Large White and 20 Creole) was used in a trial conducted in two replicates at the experimental facilities of INRA in Guadeloupe (16 ${ }^{\circ}$ Lat. N., $61^{\circ}$ Long. W.), an area characterised as a humid tropical climate. One replicate was carried out during the warm season (i.e., between February and April 2003) and the other during the hot season (i.e., between August and October 2003). During the warm season, ambient temperature and relative humidity averaged $25.3{ }^{\circ} \mathrm{C}$ and $86.0 \%$ respectively. The corresponding values for the hot season were $27.9^{\circ} \mathrm{C}$ and $83.6 \%$. The experiment started after a two week adaptation period when the animals were 14-wks old and lasted until the pigs reached $90 \mathrm{~kg}$ live BW. For each replicate, the pigs were divided into two groups of 10 animals based on their breed (Creole vs. Large White). The pigs were housed in an open front fattening unit and therefore they were exposed to natural light, temperature and relative humidity levels. The animals had 24-h access to feed (9.0 MJ net energy and $158 \mathrm{~g}$ per kg crude protein) and water.

The animals were slaughtered at about $90 \mathrm{~kg} \mathrm{BW}$ after a 24-h fasting period by manual low voltage electrical stunning. Skin samples of about $2-4 \mathrm{~cm}^{2}$ were collected from the last dorsal rib before scalding and dehairing. These samples were fixed in $10 \%(\mathrm{w} / \mathrm{v})$ buffered formalin fixed and embedded in paraffin. Sections of a thickness of six micrometers were cut both perpendicular and parallel to the surface from a few different areas of each sample and they were stained with Hematoxylin, Eosin and Safran (HES), Trichrome blue, Fontana, Giemsa, Toluidine blue and Cresyl violet solutions.

Epidermis and dermis thicknesses were determined from vertical sections of skin (two slices per animal) using the Leica Qwin software (Leica imaging system, Cambridge). Dermis and sweat gland surfaces and hair follicle density were also measured from vertical sections of skin using Image $\mathrm{J}$ software (NIH, http://rsb.info.nih.gov/ij/). According to Mowafy and Cassens [21] and also based on our results in pigs, sweat glands and hair follicles generally exist in the ratio of one-to-one. In consequence, we assumed that sweat gland density was equal to the number of hair follicles. Mast cells were recognised by their metachromatic granules using slices stained with Giemsa (20\% in aqueous solution) and their density was obtained by counting 3 slices per animal.

Epidermis and dermis thicknesses, as well as dermis surface were not evenly distributed and they were submitted to a logarithm transformation. Data were submitted to an analysis of variance including the effect of breed $(n=2)$, season $(\mathrm{n}=2)$ and interactions as main factors. The GLM procedure of SAS [28] was used for the statistical analyses and the least squares means procedure (PDIFF option) was used to compare means when a significant F-value was obtained. The results from the log-linear transformed variables were presented after back transformation and an approximate standard error in the original scale was calculated using the delta method [19].

\section{RESULTS AND DISCUSSION}

In the present experiment, $\mathrm{CR}$ pigs have slower growth rate (642 vs. $861 \mathrm{~g}$ per d) in the 45 to $90 \mathrm{~kg} \mathrm{BW}$ range and fatter carcasses at slaughter (23.5 vs. $10.4 \mathrm{~mm}$ for 

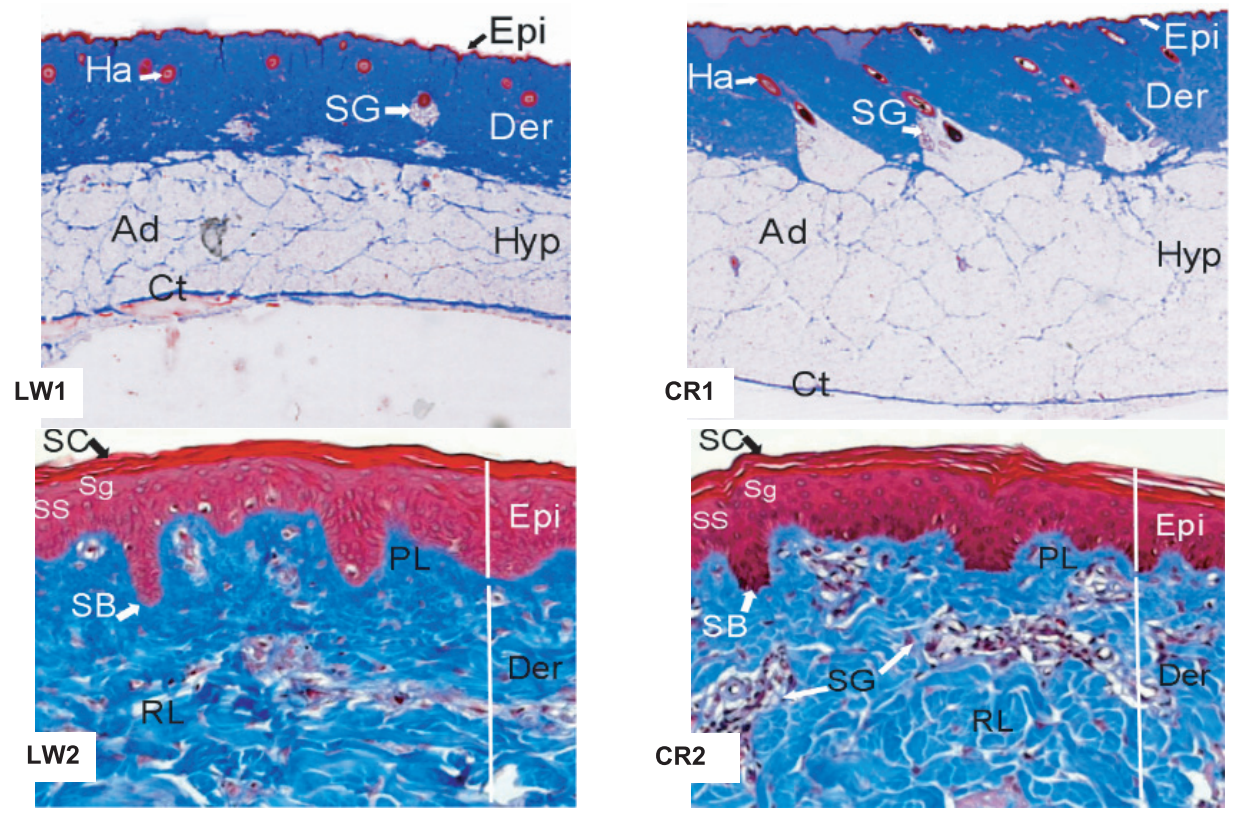

Figure 1. Vertical skin sections from the back of a Large White (LW) and Creole pig (CR). LW1 and CR1 sections show the epidermis (Epi), dermis (Der) with hair (Ha) and sweat gland (SG) structures, and hypodermis (Hyp) with adipocytes (Ad) and connective tissue border (Ct) between the outer and the inner 1 of subcutaneous adipose tissue (trichrome blue staining, objective: $1 \times$ ). LW2 and CR2 sections show the three mains layers of strata of the epidermis (Epi) (stratum basal, SB; stratum spinosum, SS; stratum granulosum, Sg; stratum corneum, SC) and the dermis (Der) (papillary layer, PL; reticular layer, RL). (Trichrome blue staining, objective: 10×).

backfat thickness at 150 days) than the LW pigs [25].

The skin of the pig is composed of three major layers with different structures and/or functions: the epidermis, the dermis and the hypodermis (Fig. 1). The hypodermis is composed of two layers of adipose tissue containing lobules of adipocytes; the two adipose layers are separated by a thin collagenous stratum; only the outer layer is represented in Figure 1.

\subsection{Epidermis}

In pigs, the epidermis consists of four major layers (Fig. 1): a thin residual cornified layer (stratum corneum), a discrete granulosum layer (stratum granulosum), a thick spinous layer (stratum spinosum) and a basal monolayer (stratum basal) which sits on the dermis [11]. The main function of the epidermis is to protect against harmful agents from the external environment (germs, ultraviolet light, chemicals) and to preserve a balanced internal environment. Moreover, the epidermis helps to control body temperature. In fact, according to the results obtained by Carvalho et al. [8], the number of cellular layers of the epidermis is negatively correlated with body temperature in cows. In other words, these results suggest that heat transfer by simple physical diffusion of excess heat from the body tissues is superior in animals with a thinner epidermis [26]. In our study, the thickness of the epidermis was affected neither 
Table I. Effect of breed and season on skin characteristics of castrated growing pigs (adjusted means).

\begin{tabular}{|c|c|c|c|c|c|c|c|}
\hline & \multicolumn{2}{|c|}{ Breed } & \multicolumn{2}{|c|}{ Season } & \multicolumn{3}{|c|}{ Statistical analysis $^{2}$} \\
\hline & \multicolumn{2}{|c|}{$\overline{\text { Creole Large White }}$} & \multicolumn{2}{|c|}{$\overline{\text { Warm Hot }}$} & $\mathrm{RSD}^{1}$ & \multicolumn{2}{|c|}{ Breed Season Breed $\times$ Season } \\
\hline $\mathrm{Nb}$. of pigs & 20 & 20 & 20 & 20 & & & \\
\hline Age at slaughter (days) & 190 & 153 & 171 & 173 & 11 & 0.00010 .6097 & 0.8162 \\
\hline \multicolumn{8}{|l|}{ Skin thickness } \\
\hline Epidermis $(\mu \mathrm{m})$ & 54 & 56 & 55 & 55 & 20 & 0.38040 .8941 & 0.3517 \\
\hline Dermis (mm) & 3.60 & 3.13 & 3.46 & 3.26 & 1.21 & 0.00190 .1693 & 0.6293 \\
\hline \multicolumn{8}{|l|}{ Sweat gland characteristics } \\
\hline Density (nb. per $\mathrm{cm}^{2}$ ) & 32.0 & 25.4 & 26.9 & 30.4 & 6.5 & 0.00280 .0971 & 0.2504 \\
\hline $\begin{array}{l}\text { Surface } \\
\left(10^{-3} \times \mu \mathrm{m}^{2} \text { per } \mathrm{mm}^{2}\right)\end{array}$ & 106 & 263 & 134 & 207 & 159 & 0.00330 .1401 & 0.2090 \\
\hline \multicolumn{8}{|l|}{ Mast cell } \\
\hline Density (nb. per mm²) & 2.52 & 1.38 & 1.68 & 2.22 & 0.51 & 0.00010 .0026 & 0.8857 \\
\hline
\end{tabular}

${ }^{1}$ Residual standard deviation.

${ }^{2}$ Analysis of variance including the effects of breed (Creole vs. Large White), season (Warm vs. Hot season) and interaction.

by breed nor by season and it averaged $55 \mu \mathrm{m}$ (Tab. I). As a result, the superiority of the CR breed with respect to heat tolerance is not related to a variation in epidermis thickness. Owing to their black skin, CR pigs have a large amount of melanin pigment in the basal layer of the epidermis (Fig. 2). In contrast, no melanin pigments are found in the skin of the LW pigs. Many studies have demonstrated that melanin provides protection against UV light (see review of [29]). According to Johansson Moller et al. [17], the dominant white coat in pigs is related to a mutation in the KIT receptor which arises with domestication.

\subsection{Dermis}

In pigs, the dermis is divided into two layers that blend together with no clear demarcation: the papillary (superficial) layer and the reticular (deep) layer (Fig. 1). According to Mowafy and Cassens [21], the dermis consists largely of dense irregular connective tissue with collagenous fibres. On the back, the pig's dermis thickness averaged $3.82 \mathrm{~mm}$. However, it was influenced by genotype (Tab. I): dermis thickness was significantly higher in CR than in LW pigs (3.60 vs. $3.13 \mathrm{~mm} ; P<0.001$ ). In contrast, Daghash et al. [9] found that buffaloes had a significantly thicker dermis than heat tolerant Jersey cows (4.57 vs. $1.43 \mathrm{~mm}$ ). They hypothesised that heat tolerance is improved with the thinning of the dermis. In addition, dermis thickness was found to be similar in Indian zebu cattle and European cattle [6]. Moreover, Dowling [12] showed that skin thickness was not essential for adaptability to a hot environment in cattle and that the functional capacity of sweat glands and type of hair appeared to be more important than the actual skin thickness in hot climates.

According to Figures 1 and 3, the pigs' sweat glands (SG) were generally distributed throughout the dermis usually in a one-to-one ratio with hair follicles in 

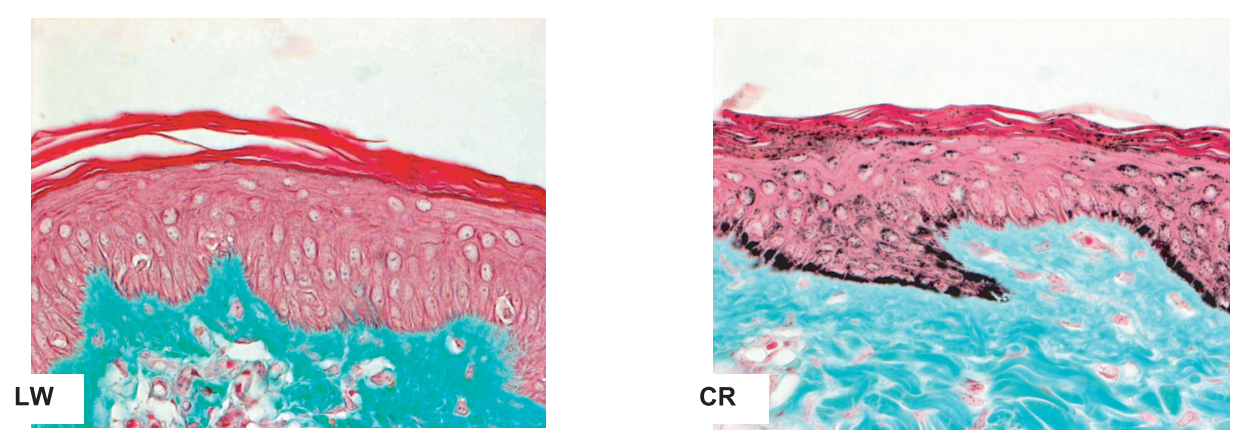

Figure 2. Vertical skin sections from the back of a Large White (LW) and Creole pig (CR). The figure shows a large amount of melanin pigments in the basal layer of the epidermis in CR and no melanin pigments in LW pigs (Fontana staining, objective: $20 \times$ ).
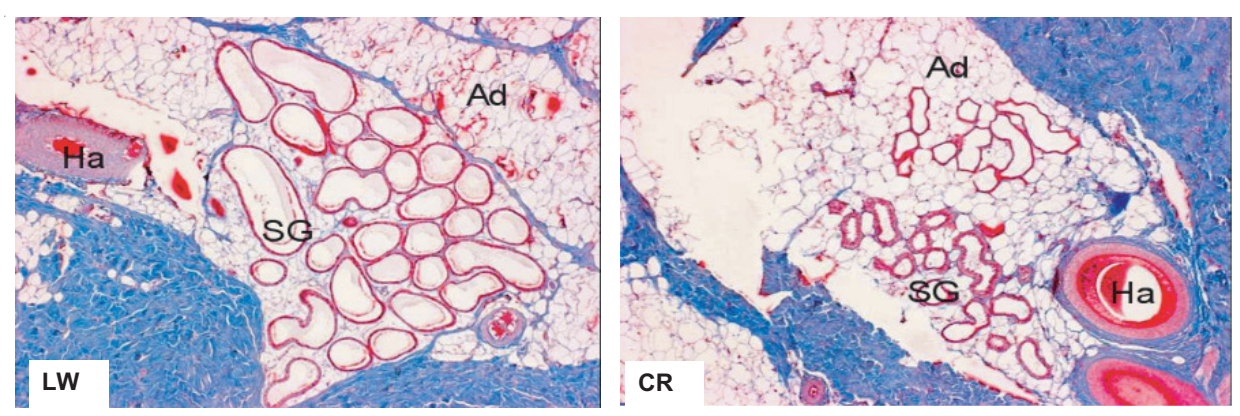

Figure 3. Vertical skin sections from the back of a Large White (LW) and Creole pig (CR); Ad, Adipocytes, SG, sweat gland and Ha, Hair structure. (Trichrome blue staining, objective: $4 \times$ ).

accordance with the observations of De Melo et al. [11]. These authors also reported that pigs' SG are of a simple, coiled, tubular and apocrine type with a secretory tubular portion located in the lower portion of the dermis and an excretory duct parallel to the hair follicles. Even though the secretory activity of SG in pigs has been demonstrated by Ingram [14], their ability to evaporate cutaneous moisture is very small in comparison with other animals such as cows [16]. In the present study, SG density for the dorsal area averaged $30 \mathrm{SG}$ per $\mathrm{cm}^{2}$, which was 10 to 100 -fold lower than the values reviewed by Berbiger [5] in cattle. According to these authors, this large variability can be explained by many factors including the body localisation of the skin sample [1] and animal related factors such as age and body weight ranges [7] or breed type [3]. Sweat gland density was significantly higher in CR than in LW (i.e., 32.0 vs. $25.5 \mathrm{SG}$ per $\mathrm{cm}^{2}$ in $\mathrm{CR}$ and in LW pigs, respectively; $P=0.003$ ). Moreover, SG surface was significantly lower in $\mathrm{CR}$ than in LW pigs (106 vs. $263 \times$ $10^{-3} \mu \mathrm{m}^{2}$ per $\left.\mathrm{mm}^{2} ; P=0.0033\right)$. According to Amakiri and Mordi [2], the rate of cutaneous evaporative loss appears to be related to a high SG density rather than SG volume. This result suggests an increase in heat loss efficiency from SG in CR pigs.

By using light microscopy, mast cells in the dermis were characterised by their metachromatic granules with a Giemsa staining substance and were found in the 


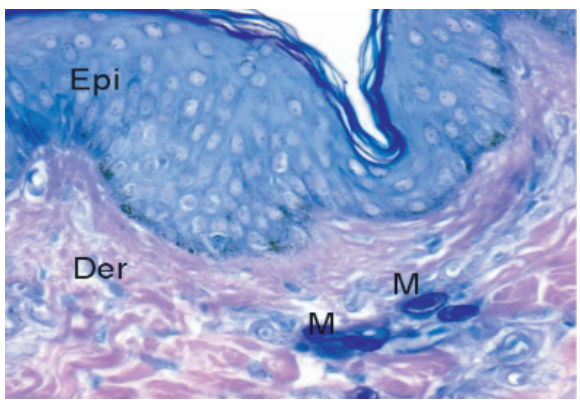

Figure 4. Vertical skin sections of a $\mathrm{CR}$ pig showing mast cells $(\mathrm{M})$ found in the dermis (Der) (Giemsa staining, objective: $20 \times$ ).

dermis (Fig. 4). The effects of breed and season on mast cell density are presented in Table I. On average, mast cell density was 2 cells per $\mathrm{mm}^{2}$ which was comparable to the values reported by Monteiro-Riviere and Stromberg [20] in pigs at 14 weeks of age (i.e., 2.9 mast cells per $\mathrm{mm}^{2}$ ) but much lower than values reported in dogs and humans (i.e., 30 to 50 mast cells per $\mathrm{mm}^{2}$ ) [4]. Irrespective of the breed, mast cell density was higher during the hot season ( 2.22 vs. 1.68 mast cells per $\mathrm{mm}^{2}$ in the warm season; $P<0.001)$. In rodents, Schmelz and Petersen [27] suggested that mast cells could be implicated in vasodilatation in skin vessels during an experimental thermal stimulation. In other words, the high density of mast cells during the hot season would imply an increase of heat dissipation. Moreover, a higher density of mast cells was found in the dermis of CR pigs (2.52 vs. 1.38 mast cells per $\mathrm{mm}^{2} ; P<$ 0.001). Similarly, Komatsu et al. [18] reported a higher mast cell density in the dermis of the Meishan pig when it was compared with Duroc, LW or Landrace pigs. In addition, the Meishan breed was also characterised by a severe eosinophil infiltration in the dermis and high anaphylactic peptide levels in the serum. According to these histopathological findings, Komatsu et al. [18] suggested a genetic variation in skin immune responsiveness between Meishan and conventional breeds. Our results support this hypothesis but the mechanisms underlying this breed difference in skin sensitivity to disease remains to be investigated. Moreover, it can be hypothesised that unconventional breeds such as the Meishan or Creole breed could be used for comparative studies designed to assess mast cell function. According to the possible implication of mast cells in cutaneous vasodilatation, our results would suggest a higher capacity of the CR pigs to redirect blood from the internal organs to the skin and thereby increase heat loss.

\subsection{Hypodermis}

The hypodermis consisted largely of adipose tissue and loose connective tissue (Fig. 1). The adipose tissue sometimes formed a dome-like structure around the roots of the hair follicle particularly in CR pigs (Fig. 3). Moreover, the outer layer of subcutaneous adipose tissue appeared to be thicker in CR than in LW pigs. This effect was connected to their higher backfat thickness [12]. In the present work, the feed offered to CR pigs was formulated according to the recommendations reported for LW pigs. Since the nutritional requirements for growth are critically lower in CR than in LW pigs (Renaudeau et al., unpublished results), the higher backfat thickness in CR pigs is mainly related to an inadequate nutrient supply relative to their growth potential.

\section{CONCLUSION}

In conclusion, it is doubtful that differences in skin histology and/or sweat gland histometry alone explain those observed in heat tolerance between breeds in previous studies ([4] Renaudeau et al., unpubished results) but would support a better heat tolerance in CR than in LW pigs. In addition, 
the LW pigs used in this trial have been living for several generations in tropical humid conditions. From this, it can also be hypothesised that the lack of a marked effect of breed in skin characteristics could be related to the acclimatisation of LW pigs to local climatic conditions.

\section{ACKNOWLEDGEMENTS}

The authors wish to thank B. Bocage, G. Gravillon, M. Hilaire, M. Lehoucq, A. Marel, R. Deom, D. Van Vlaender, E. Depiereux for their technical assistance.

\section{REFERENCES}

[1] Amakiri S.F., Sweat gland measurements in some tropical and temperate breeds of cattle in Nigeria, Anim. Prod. 18 (1974) 285-291.

[2] Amakiri S.F., Mordi R., The rate of cutaneous evaporation in some tropical and temperate breeds of cattle in Nigeria, Anim. Prod. 20 (1975) 63-68.

[3] Amakiri S.F., Onwuka S.K., Quantitative studies of sweating rate in some cattle breeds in a humid tropical environment, Anim. Prod. 30 (1980) 383-388.

[4] Auxilia S.T., Hill P.B., Mast cell distribution, epidermal thickness and hair follicle density in normal canine skin: possible explanations for the predilection sites of atopic dermatitis? Vet. Dermatol. 11 (2000) 247-254.

[5] Berbigier P., Bioclimatologie des ruminants domestiques en zone tropicale, INRA, 1988, pp. 1-237.

[6] Bhayani D.M., Patel J.M., Thermoregulatory structures and shrinkage percentage during processing of skin biopsie in the Kandrej cow, Indian J. Anim. Sci. 59 (1989) 339-343.

[7] Bhayani D.M., Vyas K.N., Effect of age and high ambient temperature on sweat gland characteristics in Gir cattle, Indian J. Anim. Sci. 60 (1990) 439-441.

[8] Carvalho F.A., Lammoglia M.A., Simoes M.J., Randel R.D., Breed affects thermoregulation and epithelial morphology in imported and native cattle subjected to heat stress, J. Anim. Sci. 73 (1995) 3570-3573.
[9] Daghash H.A., Salem I.A., Zenhom M., Salima A.E., Skin thickness and some hair coat characteristics of water Buffaloes and Jersey cows under subtropical condition, Buffalo J. 1 (1999) 81-91.

[10] D'Allaire S., DeRoth L., Physiological responses to treadmill exercise and ambient temperature in normal and malignant hyperthermia susceptible pigs, Can. J. Vet. Res. 50 (1986) 78-83.

[11] De Melo V.R., Valeri V., Orsi A.M., The fine structure of the swine sweat gland. I. The acini, Anat. Anz. 156 (1984) 51-56.

[12] Dowling D.F., The significance of the thickness of cattle skin, Aust. J. Agr. Sci. 62 (1964) 307-314.

[13] Holmes C.W., Close W.H., The influence of climatic variables on energy metabolism and associated aspects of productivity in the pig, in: Haresign W., Swan H., Lewis D. (Eds.), Nutrition and the climatic environment, Butterworths, London, 1977, pp. 5173

[14] Ingram D.L., Stimulation of cutaneous glands in the pig, J. Comp. Pathol. 77 (1967) 93-98.

[15] Ingram D.L., Legge K.F., The influence of deep temperatures and skin temperatures on peripheral blood flow in the pig, J. Physiol. 215 (1971) 693-707.

[16] Ingram D.L., Heat loss and its control in pigs. Heat loss and its control in pigs, in: Monteith J.L., Mount L.E. (Eds.), Butterworths, London, 1973, pp. 235-254.

[17] Johansson Moller M., Chaudary R., Hellmén E., Höyheim B., Chowdhary B., Andersson L., Pigs with the dominant white color phenotype carry a duplication of the KIT gene encoding the mast/stem cell growth receptor, Mamm. Genome 7 (1996) 822-830.

[18] Komastu M., Yoshihara S., Akita T., Goto N., Immunological characteristics and skin structure of the Meishan pig: serum complement activity, serum C3 level and immune response, Anim. Sci. J. 70 (1999) 393-398.

[19] Littel R.C., Milliken G.A., Stroup W.W., Wolfinger R.D., SAS System for Mixed Models, SAS Institute Inc., Cary, NC, 1996.

[20] Monteiro-Riviere N.A., Stromberg M.W., Ultrastructure of the integument of the domestic pig (Sus scrofa) from one through fourteen weeks of age, Zbl. Vet. Med. C. Anat. Histol. Embryol. 14 (1985) 97-115.

[21] Mowafy M., Cassens R.G., Microscopic structure of pig skin, J. Anim. Sci. 41 (1975) 1281-1290. 
[22] Nienaber J.A., Hahn G.L., Eigenberg R.A., Korthals R.L., Yen J.T., Harris D.L., Genetic and heat stress interaction effects on finishing swine, American Society of Agricultural Engineers, in: Bottcher R.W., Hoff S.J. (Eds.), Bloomington, Minnesota, 1997, pp. 1017-1023.

[23] Renaudeau D., Effects of short-term exposure to high ambient temperature and relative humidity on thermoregulatory responses of European (Large White) and Carribbean (Creole) restrictively fed growing pigs, Anim. Res. 54 (2005) 81-93.

[24] Renaudeau D., Giorgi M., Silou F., Weisbecker J.L., Influence du climat tropical et du type génétique sur les performances zootechniques et le comportement alimentaire du porc en croissance entre 45 et $90 \mathrm{~kg}$, Journées de la Recherche Porcine en France 37 (2005) 259-266.
[25] Renaudeau D., Giorgi M., Silou F., Weisbecker J.L., Effect of breed (lean or fat pigs), sex, and season on performance and feeding behaviour of group housed growing pigs in a tropical climate, Asian-Aust. J. Anim. Sci. (in press).

[26] Saravanakumar V.R., Thiagarajan M., Comparison of sweat glands, skin characters and heat tolerance coefficients amongst Murrah, Surti and non-descript buffaloes, Indian J. Anim. Sci. 62 (1992) 625-628.

[27] Schmelz M., Petersen L.J., Neurogenic inflammation in human and rodent skin, Physiology 16 (2001) 33-37.

[28] SAS, SAS/STAT User's Guide (version 7, 4th ed.), SAS Institute Inc., Cary, NC, 1997.

[29] Taylor S.C., Skin of color: biology, structure, function, and implications for dermatologic disease, J. Am. Acad. Dermatol. 46 (2002) S41-S62. 
